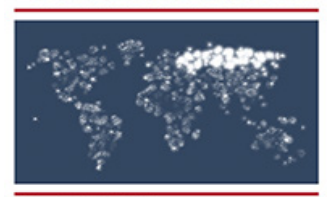

\title{
A.P. Skovorodnikov's binary conception of linguistic ecology: definitional and disciplinary justifications
}

\section{Galina A. Kopnina \& Oksana V. Magirovskaya}

To cite this article: Galina A. Kopnina \& Oksana V. Magirovskaya (2019) A.P. Skovorodnikov's binary conception of linguistic ecology: definitional and disciplinary justifications, Russian Journal of Communication, 11:2, 95-108, DOI: 10.1080/19409419.2019.1621191

To link to this article: https://doi.org/10.1080/19409419.2019.1621191

曲 Published online: 27 May 2019.

Submit your article to this journal $\pi$

山 Article views: 15

Q View related articles $₫$

View Crossmark data 